\title{
The Human Dimension of Pollution Policy Implementation: Air Quality in Rural China
}

\section{Citation}

William P. Alford, Robert P. Weller, Leslyn Hall, Karen R. Polenske, Yuanyuan Shen \& David Zewig, The Human Dimension of Pollution Policy Implementation: Air Quality in Rural China, 11 J. Contemp. China 32 (2002).

\section{Published Version}

doi:10.1080/10670560220152300

\section{Permanent link}

http://nrs.harvard.edu/urn-3:HUL.InstRepos:12019077

\section{Terms of Use}

This article was downloaded from Harvard University's DASH repository, and is made available under the terms and conditions applicable to Other Posted Material, as set forth at http:// nrs.harvard.edu/urn-3:HUL.InstRepos:dash.current.terms-of-use\#LAA

\section{Share Your Story}

The Harvard community has made this article openly available.

Please share how this access benefits you. Submit a story.

Accessibility 


\title{
The Human Dimensions of Pollution Policy Implementation:
}

\section{Air Quality in Rural China}

\author{
by \\ William P. Alford*, Robert P. Weller**, Leslyn Hall***, \\ Karen R. Polenske****, Yuanyuan Shen*, and David Zweig*****
}

The government of the People's Republic of China has become increasingly concerned with its serious environmental problems over the past decade. One study suggests that as of the mid 1990's, urban air and water pollution alone cost the Chinese economy US $\$ 32.3$ billion annually in premature deaths, morbidity, restricted activity, chronic bronchitis and other heath effects, which is equal to more than 9 percent of Gross National Product. ${ }^{1}$ That study estimates that 110,000 premature deaths occur each year, primarily in rural areas, as a result of indoor air

The authors wish to thank the V. Kann Rasmussen Foundation, the Harvard University Committee on the Environment, and the United States Department of Energy for their support of the research from which this article emerges. We also wish to express our gratitude to Richard Edmonds, Matthew Kohrman, Michael McElroy, Chris Nielsen, Dr. Xu Xiping and Dr. Wang Binyan and various other Chinese colleagues for their valuable, substantive advice on this piece.

\footnotetext{
*Harvard University

***Boston University

***ORC Macro

*****Massachusetts Institute of Technology

*****Hong Kong University of Science \& Technology and Department of Political Science, Queen's University, Kingston, Ontario
}

1. Todd M. Johnson, Feng Liu, and Richard Newfarmer, Clear Water, Blue Skies: China's Environment in the New Century (Washington, DC: The World Bank, 1997), p. 23. Also see Xia Guang, "An Estimate of the Economic Consequences of Environmental Pollution in China," in Vaclav Smil and Mao Yushi (coordinators), Project on Environmental Scarcities, State Capacity, and Civil Violence (Cambridge, MA: Committee on International Security Studies, American Academy of Arts and Sciences, 1997), pp. 41-59. 
pollution. ${ }^{2}$ General assessments of China's environmental problems run a range from the alarmist ${ }^{3}$ to the cautionary, ${ }^{4}$ but all agree that the problems are very serious.

In response, the Chinese government has taken a number of important and innovative policy steps to improve the situation. China was the first country to pass a national Agenda 21 policy. The PRC first established a leadership group on the environment under the State Council in 1974, and has repeatedly strengthened its institutional commitment to the environment since then. In 1998 this culminated in the creation of the ministerial-level State Environmental Protection Administration (SEPA) out of the former National Environmental Protection Agency (NEPA). The concern for environmental protection is now shown in five-year plans and through the overhaul and strengthening of environmental laws. Recent years have also seen the initiation of high profile environmental campaigns, such as that restricting the use of leaded gasoline in large cities and that promoting reforestation in the aftermath of the Yangzi River floods of 1998.

Yet the Chinese state has also been plagued with problems in implementing and enforcing its environmental policies, especially in rural areas. ${ }^{5}$ Serious local environmental abuse regularly occurs, especially where there are overpowering economic incentives to exploit the environment for immediate gain--it is not uncommon, for example, to see people causing serious erosion by opening steep slopes (beyond the 25-degree legal maximum) to agriculture in poor areas, or losing windbreaks by illegally harvesting roadside trees for firewood. ${ }^{6}$ Large, state-owned enterprises, often utilizing antiquated equipment, collective enterprises, which often create income for local

2. Clear Water, Blue Skies, supra note 1.

3. Lester R. Brown, Who Will Feed China? Wake-up Call for a Small Planet (New York: Norton, 1995); Vaclav Smil, The Bad Earth: Environmental Degradation in China (Armonk, NY: M. E. Sharpe, 1984); Mark Hertsgaard, "Our Real China Problem," Atlantic Monthly, (November 1997), pp. 97-114.

4. Kenneth Lieberthal, Governing China: From Revolution to Reform (New York: Norton, 1995); China's Governing System and Its Impacts on Environmental Policy Implementation, Report for the Woodrow Wilson Center, Environmental Change and Security Project, China Environment Series 1 (Washington, DC: n.p., 1997), pp. 290-291.

5. See the introduction in David M. Lampton (ed.), Policy Implementation in Post-Mao China (Berkeley and Los Angeles: University of California Press, 1987).

6. Problems implementing environmental policy are not new in China. See Peter C. Perdue, Exhausting the Earth: State and Peasant in Hunan, 1500-1850 (Cambridge, MA: Council on East Asian Studies, Harvard University, 1987); Richard Lewis Edmonds, Patterns of China's Lost Harmony: A Survey of the Country's Environmental Degradation and Protection (London: Routledge, 1994); Mark Elvin and T. J. Liu, (eds.), Sediments of Time: Environment and Society in Chinese History (New York: Cambridge University Press, 1997). 
governments (including street committees in urban areas) and township-village enterprises, which may lack adequate funds for clean production, are also all often polluting.

This article reports the initial results of a collaborative project on the successes and failures of environmental policy implementation in Anqing, a small city and its rural hinterland on the Yangzi River in southern Anhui province. Our goal has been to learn when and how local citizens become environmentally responsible, and to draw appropriate lessons for policy. This includes two broad topics: First, we show how citizens receive basic environmental knowledge through schools, the media, local meetings, or personal experience (such as health problems). Specifically, the sections that follow examine the hypotheses that environmental awareness comes from the experience of environmental problems, from environmental education, or from increased wealth. Second, we consider whether people are able to act on that knowledge through their economic choices or their political and legal options. We discuss in particular the roles of recent legal reforms and local elections.

In spite of the policy innovations of recent years, our findings to date are that the Anqing citizenry neither has much knowledge about environmental problems -- including that of indoor air pollution which afflicts many of them -- nor many methods for addressing these problems of which they are aware. For instance, 63 percent of our respondents had never heard of the term “environmental protection" (huanjing baohu). ${ }^{7}$ Government concerns about the environment have not been carried down to this level, and institutional innovations such as the expanding legal system or village elections have yet to lead to any apparent differences or consequences in the ways in which people solve environmental problems. This article will begin to examine why these measures to date have had little effect in the countryside, and consider what policy mechanisms might fruitfully be considered to enhance their effectiveness.

We have concentrated on issues of indoor air pollution in two of Anqing's rural counties. Although natural gas has become increasingly important in urban areas of China, coal, wood and other biomass remain the primary heating and cooking fuels for the great majority of Chinese ${ }^{8}$. The urban area of Anqing has some large state-owned industry, and the rural areas (accounting for about 90 percent of Anqing's population of 5.8 million) are primarily agricultural, with somewhat

7. The question read, "Have you ever heard of environmental protection?"

8. Rural household energy use accounted for virtually all the biomass (wood and crop stalks) and about 10 percent of the coal used in China in 1992. Jonathan E. Sinton (ed.), China Energy Databook (Berkeley: Lawrence Berkeley Laboratory, 1996), pp. IV-16, IV-76. Even in cities, older buildings generally have no plans to convert to new energy sources and "floating population" settlements have no access to gas for heat. 
less local industry than more coastal regions.

The data we report on here stem from two main components. First, we are using information already gathered for a large-scale study (conducted under the auspices of the Harvard University School of Public Health) of the epidemiology of asthma. This includes measures of lung function, as well as reports of disease including asthma and bronchitis. The availability of this data set was one of our primary reasons for choosing Anqing. Second, in October 1997 we conducted a household survey of 244 people from families who had already been involved in the asthma study. ${ }^{9}$ We asked questions concerning their knowledge of environmental protection, perceptions of environmental quality, sources of knowledge about the environment, methods of handling environmental problems, as well as household energy use, economic situation and demographics. ${ }^{10}$

Rural Anqing is no more representative of all China than any other local area can be. We do, however, believe that these results are at least suggestive of the general situation over large areas of rural China that have similar education levels, health situations, and fuel use patterns.

\section{Conventional Wisdom}

A discernible level of pollution may be a necessary condition to attract people's attention to environmental problems, but it is rarely sufficient by itself. In some cases people have no way to realize the health or wider environmental effects of polluting activities. This is especially true when the effects are distant in time (as with the burial of hazardous wastes) or space (as with acid rain). In many other cases, people simply accept a polluted environment as a fact of life. We saw this clearly in Anqing, for example, when people were burning rice stalks in the fields after the

9. Respondents for the social survey were selected from the epidemiology study as follows: (1) 25 families were randomly selected from the control group (i.e., people without diagnosed asthma) in each of two counties enrolled in the asthma study; (2) for each village in which the selected families was located, we also randomly selected an equal number of families from the asthma group. We attempt to pair control families and asthmatic families, although in some cases it was not possible to select as many asthma families as control families. Within each family we attempted to interview at least two adults between the ages of 18 and 65; where possible we interviewed as many as three. We completed interviews in 133 households (having attempted them in 157) for the total of 244 individual interviews. The response rate of households was 84 percent. The method of subject selection does not allow us to make statistical generalizations beyond our respondents. The results are suggestive of wider trends, but further research will be needed to draw more general conclusions. Interviewers were all young people affiliated with the local public health bureaus; they underwent two full days of training before beginning the study. All of the interviewing was completed in an eight-day period in October 1997.

10. This work took place under the auspices of the Harvard University Committee on the Environment (UCE) China Project, in cooperation with the Anqing Municipal Public Health Department. 
harvest (which both fertilizes the soil and helps control pests). This filled the skies with dark haze, even closing the municipal airport at one point, but only 36 percent of our respondents considered this action dangerous to the environment. ${ }^{11}$ A similar point might be made about the burning of yard waste forty years ago in the United States or the coal smoke that polluted London's skies through the mid-nineteenth century. No environmental policy beyond simple coercion is likely to succeed without first establishing some public recognition of the importance of its goals, and we therefore turn to that problem first.

Arguably, there are at least three broad mechanisms that can lead people to identify environmental problems. The first is a crisis that focuses attention on a problem. Many of the crucial turning points in the development of environmental consciousness around the world happened because people suddenly linked environmental conditions with severe problems: the mercury poisoning in Minamata Bay catalyzed changes in Japanese pollution law; Love Canal fostered environmental awareness through serious health problems in the United States; and the accidents at Three Mile Island and Chernobyl helped change thinking about nuclear energy.

There have been many isolated cases of anti-pollution demonstrations in China, especially after major water or air pollution episodes. Jing documents 47 cases of forceful popular protest in China, nearly all in response to immediate local environmental problems. ${ }^{12}$ In one case, for example, villagers facing obvious pollution and serious animal and human health problems challenged factory management to drink from their contaminated stream, and later blockaded the offending factory--techniques widely used elsewhere. ${ }^{13}$ The crisis can also take a more individual form when family health problems are tied to local pollution. In our case, we hypothesize that people with lung problems including asthma or chronic bronchitis will make a connection with indoor air pollution. As in most of China, women do the majority of the cooking in this area, and we examine below the possibility that they will show greater health effects, and greater concern for environmental issues. Their greater role in child care may also encourage stronger environmental awareness.

11. The question was, "Do you think that burning rice stalks after the harvest produces air pollution that is very harmful to the environment, relatively harmful, not too harmful, or not harmful at all?" The figure of 36 percent combines those who answered that it was relatively or very harmful.

12. Jun Jing, "Environmental Protests in Rural China," in Mark Selden and Elizabeth Perry (eds.), Chinese Society: Change, Conflict and Resistance (London and New York: Routledge 2000), pp. 143-60.

13. Ibid., pp. 146-8. 
Education provides a second mechanism through which environmental awareness can be fostered. Indeed, in many parts of the world, general education levels correlate with environmental consciousness, and we investigate whether or not this holds true in Anqing. ${ }^{14}$ Students in Chinese schools are routinely exposed to basic information about sanitation, and have often taken part in such environmentally related activities as street cleaning and tree planting activities. In the Chinese context it is equally important to look at official information campaigns. The largest in recent years concerned the Huai River cleanup, which was a well-publicized effort aimed at paper mill pollution in central China, including the northern part of Anhui province. Approximately one thousand paper mills were closed along the river (although may have since reopened), and the publicity about the action was widely disseminated. ${ }^{15}$ National officials have stressed the need to observe environmental legal requirements. The much-publicized movement to popularize legal knowledge (puji falü zhishi de huodong or "pufa") has included the Environmental Protection Law, and state media have accorded considerable attention to the invocation of environmental law by both senior officialdom and ordinary citizens. ${ }^{16}$

Third, there is the more controversial hypothesis that wealth creates environmental consciousness, and that environmentalism is thus fundamentally a middle class movement. More accurately, environmentalist organizations (as opposed to local anti-pollution movements) are dominated in many countries by the "new" middle class--lawyers, teachers, scientists--and other people in the knowledge industries instead of the "old" production sector. ${ }^{17}$ Others have challenged this idea, arguing instead that environmental concern can develop among the poor

14. See, for example, Ronald Inglehart's argument that postmaterialist values (including environmental values), education, and wealth are interrelated. Ronald Inglehart, Culture Shift in Advanced Industrial Society (Princeton, NJ: Princeton University Press, 1990).

15. Hertsgaard, "Our Real China Problem."

16. The pufa campaigns are the subject of Mechtild Exner, "The Convergence of Ideology and the Law: The Functions of the Legal Education Campaign in Building a Chinese Legal System," Issues and Studies 31, 8 (1995), pp. 68-102(August 1985).

17. William Tucker, Progress and Privilege: America in the Age of Environmentalism (Garden City, NY: Anchor, 1982); Michael Redclift, Sustainable Development: Exploring the Contradictions (London: Methuen, 1987); María Pilar García, "The Venezuelan Ecology Movement: Symbolic Effectiveness, Social Practices, and Political Strategies" in Arturo Escobar and Sonia E. Alvarez (eds.), The Making of Social Movements in Latin America: Identity, Strategy and Democracy (Boulder, CO: Westview, 1992); Robert P. Weller and Hsin-Huang Michael Hsiao, "Culture, Gender and Community in Taiwan's Environmental Movement" in Arne Kalland and Gerard Persoon (eds.), Environmental Movements in Asia (Surrey: Curzon, 1998), pp. 83-109. 
through efforts to defend local resources, or from education and the media. ${ }^{18}$ Our data allow us to weigh the effects of wealth on environmental awareness and to compare them with the effects of local pollution experience, education and the media.

Even people who are aware of environmental problems may not be able to do anything about them if they lack economic ability or political power. Most of China's policy innovations that might affect local pollution have involved building better political institutional capacity to identify and manage environmental problems. ${ }^{19}$ We will examine two of the most important areas that Chinese and foreign observers believe may encourage people to improve the environment more effectively. First, extensive reforms in environmental law and the legal system generally could, in principle, empower both the government and local people to control major polluters. Second, greater local political control through village committee elections or other forms of grass roots participation, including writing petitions to higher level officials, could, again in principle, allow people to elect local officials sympathetic to their environmental concerns. Increasing the popular legitimacy of local leaders might also help the government implement even its most difficult policies locally. ${ }^{20}$

In practice, however, we find that none of these new policies is having much effect on environmental practice among Anqing villagers. While villagers may sometimes complain about pollution or sanitation problems, only a handful are familiar with the relevant laws and even fewer have invoked the law on environmental or any other issues. Few people report having ever taken any kind of environmental action beyond compulsory tree planting or street cleaning. Our respondents suggest that the environment is not an important issue for village committees, and that the people who elect them do not expect it to be. Anqing's municipal government has an EPB, but not all of the counties have established them, their resources are limited, and they do not really reach into these villages. We will discuss each of these initiatives and their effects in the sections that follow.

18. Steven R. Brechin and Willett Kempton, "Global Environmentalism: A Challenge to the Postmaterialism Thesis?” Social Science Quarterly 75, 2 (1994), pp. 245-269.

19. The economics of the shift away from coal to natural gas and liquified petroleum gas in many urban areas is part of this process, and relies in part on changing building codes governing new construction and on changing the economic incentives for using different fuels. We do not discuss this issue here because these changes have generally not yet reached the countryside, and our sample includes very few people (22 of the 133 households interviewed) who have switched fuels. Wood and rice stalks remain the dominant forms of domestic fuel for heating and cooking in this area.

20. Daniel Kelliher, "The Chinese Debate Over Village Self-government," China Journal 37 (1997), pp. 63-86. 


\section{Indoor Air Pollution: Exposure and Effects}

Rural household energy use has received little attention, but it accounted for 24 percent of all energy consumption in China in 1992. ${ }^{21}$ The main sources of domestic fuel in rural Anqing are wood and rice straw. Nearly every household uses such biomass, and it is the primary source of energy for the great majority. ${ }^{22}$ This is a common pattern in China: rural households burn virtually all the biomass (wood, crop stalks, and dung) used in the country, and biomass accounts for 70 percent of the fuel used by rural households nationwide. ${ }^{23}$

Cooking is the most important activity exposing people to pollution from these fuels in Anqing. Kitchens are not especially air tight, which helps cooking fumes dissipate, but the people working directly at the stove are exposed to higher concentrations of pollutants. In Anqing families, two people are generally most at risk from cooking: one who keeps the stove stocked with fuel (often the grandmother), and another who does the cooking itself (often the mother). In local community-based epidemiological surveys, women constituted 77 percent of the people who cook, and generally have more exposure than their husbands and sons to the major source of indoor pollution daily, although they did not report severe pollution in the survey (see Table 1). ${ }^{24}$ The other main domestic use for fuel is localized winter heating for an average of 2.5 months each year. ${ }^{25}$ The seniors and children who stay at home will have higher exposure to the open coal stove within the living room in winter. The more months a household heats in winter, the more likely its members are to show impaired lung function. ${ }^{26}$ Nearly everyone has electricity, but it is

21. Sinton, China Energy Databook, pp. IV-63.

22. Our data show that 97 percent (129/133 households) relied on biomass for some of their energy needs, and 83 percent use biomass as their primary energy source. The most common supplementary source of energy is electricity, whose ultimate source is usually coal.

23. Sinton, China Energy Databook, pp. IV-16, IV-76; Ruicong Peng, Lihua Wang, Hong Wang and Xiping Xu (eds.), “Air Pollution from Residential Energy Use in China” MS, 1996, p. 5.

24. These data are derived from all eight counties included in the Anqing Asthma Epidemiology Survey conducted by Professor Xu Xiping and his colleagues, rather than the pilot study.

25. About 90 percent of households heat during the winter. The most commonly mentioned fuel was kerosene ( 62 percent of households who cited a fuel type), followed by biomass (16 percent) and coal (13 percent).

26. This is based on correlations between months of heating (0-5) and two health indicators: (1) the ratio of air released in a quick exhale to average total lung capacity (lower levels indicate reduced capacity); the 
used almost entirely for light and television. One of the few rural studies has been Xu's earlier collaborative effort in Anqing, which concluded that the use of coal, wood, and hay for home cooking is significantly associated with rates of asthma and wheezing (Xu et al. 1996). ${ }^{27}$ Given actual social patterns, this means that women are likely to suffer the most from the effects of indoor air pollution. In addition, smoking is another indoor pollution source, especially for male adults (see Table 1).

Without direct measurements of indoor and outdoor air quality in these areas, we cannot draw any final conclusions about direct assessment of the dose-response relationship between the concentration of indoor pollution and its health effects. Although our data on the relationship between indoor pollution and health are still preliminary, however, they do suggest an association. Interview data, for example, suggests an association between cooking exposure and lung function (see Table 2) and major respiratory symptoms, as well as asthma prevalence. For people, especially female adults who cook almost daily in the kitchens, the analysis consistently showed lower lung capacities and more chronic and severe respiratory symptoms such as coughing, phlegming, shortness of breath and persistent wheezing for both male and female adults (see Table $3)$.

Most studies of indoor air pollution and health in China have been urban and have concentrated on coal, and show a clear relationship between indoor coal use and multiple health effects such as acute and chronic respiratory symptoms, disease, and hospital admission. ${ }^{28}$ For example, Beijing women in coal-burning households have more respiratory problems than women in gas-burning households. ${ }^{29}$ Similar studies have also shown that burning biomass releases many

correlation here is $-.1577(\mathrm{p}=.031)$; and (2) an additive index in which one point was given for people reporting asthma, frequent coughing, wheezing ever, and regularly bringing up phlegm (possible values were $0-4$, with higher values indicating greater lung problems); the correlation with winter heating was .2382 ( $\mathrm{p}=.001$ ). Our data are less clear on cooking effects, in part because of the powerful effects of smoking. While we do not examine smoking in this article, our data show that smoking is the factor most closely associated with respiratory problems.

27. Xiping Xu, Tianhu Niu, David C. Christiani, Scott T. Weiss, Changzhong Chen, Yusheng Zhou, Jianhua Yang, Zhian Fang, Zhujiu Jiang, Liang Wannian and Fangzhen Zhang (eds.), "Occupational and Environmental Risk Factors for Asthma in Rural Communities in China" in Journal of Occupational and Environmental Health 2 (1996). For an overview of indoor air pollution issues in the United States, see Wayne R. Ott and John W. Roberts, "Everyday Exposure to Toxic Pollutants," Scientific American (February 1998), pp. 86-91.

28. Xu Wang, et al., "Association between air pollution and low birth weight: a community-based study," Environmental Health Perspectives, 105, 5 (May 1997), pp. 514-520.

29. Xiping Xu, et al., "Association of indoor and outdoor particulate level with chronic respiratory 
of the same pollutants as coal, albeit in lower concentrations. ${ }^{30}$

For women, more than for men, respiratory problems increase perceptions of environmental problems and the importance placed on environmental protection. This may reflect an accurate understanding of the actual causes. Many respiratory problems in men stem from smoking, which smokers generally do not consider an environmental problem, more than the indoor air pollution factors we examine here. On the other hand, very few women smoke in rural Anqing. Based on our lung function data, after adjusting for the effect of smoking, the reverse association of cooking exposure and health effects still existed among female non-smokers in a manner that was consistent, if not remarkable. Our interviews, though limited in number, revealed that women rightly blame their own health problems more on environmental factors. For men, who smoke much more and cook much less, smoking tends to overwhelm other effects. Nevertheless, our results implied that people with more chronic symptoms might be more likely to be aware of the pollution engendered during cooking. At least for women, and possibly for men, as well, health crises might foster a consciousness of the consequences of people's environmental actions. It appears that most Anqing residents suffer the problems of chronic exposure, and do not, in general, react in a dramatic fashion. In the following section we examine the other mechanisms that might lead to greater environmental awareness and action.

\section{Education and Campaigns}

Campaigns have always been an important method of policy implementation in socialist China and have on occasion been used to raise awareness of environmental problems and mechanisms that might manage them. ${ }^{31}$ Campaigns involve both the broadcast media (over all of which the state has strong control) and political organizations down to the local level. These local units educate people about the campaign through a variety of means, including the loudspeaker systems that have been installed in villages and factories, slogans painted on walls and drawn on factory blackboards, and village meetings. They may also organize people to take specific actions, which have been anything from swatting flies to eliminating "capitalist roaders." In Anhui, the 240 government offices and 2,376 officials concerned with the environment devoted considerable efforts to environmental "propaganda and education," according to the China Environmental

illness," American Review of Respiratory Disorders, 148, 6 Pt. 1, (December 1993), pp. 1516-1522.

30. Peng, et al., "Air Pollution."

31. Lester Ross, Environmental Policy in China (Bloomington, IN: Indiana University Press, 1988). 
Yearbook for 1996, mounting 1,921 programs through television and other mass media, conducting 350 additional propaganda activities, and holding 128 training courses. $^{32}$

We found, however, that only 12 percent of our sample (29 people, including only 6 women) had ever heard about or participated in any environmental campaign. ${ }^{33}$ Even these people were usually referring to the tree planting efforts that China has promoted for many years. We conclude that government concerns about specific environmental issues, which have been stated so clearly in some contexts, have not reached rural populations, or, at least, not this population.

Among the 29 people who did claim some knowledge of environmental campaigns, television was by far the most important source of information (cited by 59 percent). Local village public address broadcasts were cited by less than half as many people, and only 10 percent mentioned newspapers. This is consistent with our finding that television sets are the single most common household appliance. Nearly every household has one (231/244)--more than the number with radios, fans, or even bicycles.

The importance of television and the general ignorance of national environmental campaigns are also consistent with the low levels of education in the area. Less than half the people in the sample had gone beyond elementary school, and 39 percent had no education. Rates for women were even lower, with 48 percent never having attended school. Even people with a few years of elementary education are often functionally illiterate in China. One could hardly expect print media to be very effective under these circumstances.

When we asked people why they had never acted on perceived environmental problems, 40 percent of those who responded (36/92) cited lack of knowledge--they said they did not know what to do. These data suggest that environmental policy could be made more effective by improving education in two ways: immediate education, probably through television, about environmental issues (provided it can be made interesting enough to keep viewers' attention), and longer term investment in raising the level of literacy. The problems of education will come up again in the sections that follow. This obstacle is particularly pressing for women, whose literacy rate is much lower than men's, but who bear the primary brunt of indoor air pollution and who

32. Zhongguo Huanjing Nianjian Bianji Weiyuanhui, Zhongguo Huanjing Nianjian [China Environmental Yearbook] (Beijing: Zhongguo Huanjing Kexue Chubanshe, 1996).

33. The question read, "The government and Environmental Protection Bureau sometimes conduct educational campaigns for the masses about environmental matters; have you even heard of or participated locally in this sort of activity?" 
make most of the domestic fuel use decisions.

Our working conclusion about the importance of literacy finds support in the writing of scholars who have studied other dimensions of environmental activity in China. Susmita Dasgupta and David Wheeler of the World Bank, for example, have used the frequency of formal citizen complaints about the environment (through letters and visits to environmental officials) to construct a model that shows that "a $1 \%$ increase in the literacy rate seems to induce a $2 \%$ increase in environmental complaints," controlling for differences in income, pollution density, and other disparities. ${ }^{34}$ And, to take another illustration, Yuan Fang has shown, through his survey of 2,000 respondents in Beijing and Shanghai, that education level was closely related to recognition of ecological matters. ${ }^{35}$ Our own data also show a correlation between level of education and how important people consider environmental problems to be.

\section{Wealth and Environmental Behavior}

The final mechanism we hypothesized might lead to greater environmental consciousness was wealth. This suggestion comes originally from Inglehart's postmaterialism thesis, in which he argued that wealthier countries began turning from materialist to postmaterialist values-including environmentalism--several decades ago. ${ }^{36}$ This is consistent with the timing of the growth of the "knowledge classes," whose livelihood was no longer directly based in industrial production, and for whom lifestyle issues were increasingly important. Our data do suggest that wealth increases the possibility that people recognize environmental problems and place importance on environmental protection in Anqing.

We are cautious, however, about considering this as clear support for the postmaterialism thesis. Wealth is relative, and the wealthier people in rural Anqing are not particularly rich in national terms, and are rather poor by the standards of industrialized nations. Occupationally few among our sample could be identified with the knowledge class. The vast majority farm as their primary occupation (86 percent, 193/225). Only 4 percent (9/225) could be considered knowledge classes, including government workers, teachers, and professionals. Wealth is generally increasing for most of China, and this suggests that places like Anqing may develop more concern

34. Susmita Dasgupta and David Wheeler, Citizen Complaints as Environmental Indicators: Evidence from China, Report to PRDEI, World Bank, 1996, p. 11.

35. Qinglin Yuan, Zhongguo Huanjing Baoju Shihua [A History of Chinese Environmental Protection] (Beijing: Zhongguo Huanjing Kexue Chubanshe, 1989).

36. Inglehart, Culture Shift. 
for environmental problems in the future.

Our initial hypotheses that indoor pollution and health problems, more education, and greater wealth would create greater environmental awareness are partially borne out by the Anqing data. Women (who are most exposed to indoor air pollution), the educated, and the wealthy are more likely to perceive problems in their environment. In fact, we found broad local support for generic ideas of environmental protection; when we asked people to rate the importance of environmental protection and air quality on 10-point scales (with 0 being unimportant and 10 being very important), the modal answer in both cases was 8 , and only a handful gave answers below $5 .^{37}$ Our survey also indicates that more than 60 percent of respondents believe that environmental problems exist in Anqing, with more identifying air quality (roughly one quarter of all respondents) as the prime problem than any other except for water quality.

Yet we also found very little appreciation of how local actions contribute to environmental quality. For example, only about 5 percent of our respondents rated the locality where they live as relatively or very polluted. ${ }^{38}$ Only 29 percent consider cooking and heating even relatively harmful to health, and only 25 percent consider it harmful to the environment. ${ }^{39}$ People expressed somewhat more concern about industrial pollution, but, in fact, there is very little industry in the research sites. In an attempt to determine environmental awareness of their own behavior in other contexts, we also asked people what they do with litter when they are not at home. ${ }^{40}$ Only 25 percent claimed they would find a garbage can. Nearly all the rest said they would just throw it anywhere, with a few admitting that they would wait until no one was looking.

In fact, in spite of the very general concern people express about environmental quality,

37. One question read, "How important do you think fresh air is? On this scale, "0" represents very unimportant, "10" represents very important, so all the numbers between " 0 " and " 10 " represent degrees between very unimportant and very important. Please indicate on this scale which degree best represents your own opinion." The other question was, "How important do you think environmental protection is to you? [followed by the same explanation of the scale]."

38. The question read, "Do you think that the area where you live is very clean, relatively clean, a little polluted, relatively badly polluted, or very badly polluted?"

39. The questions were: "Do you think that the air pollution produced by cooking and heating is very harmful to you and your family's health, relatively harmful, not too harmful, or not harmful at all?" "Generally speaking, do you think that the air pollution produced by cooking and heating is very harmful to the environment, relatively harmful, not too harmful, or not harmful at all?"

40. The question read, "What would you normally do if you were in a public place and had things like food boxes, waste paper, or drink bottles to throw away, but could not find a garbage can? Would you just throw it any place, wait until no one was looking and then throw it away, put it someplace out of sight, go find a garbage can to throw it in, or something else?" 
our sample in rural Anqing rarely acts on its concerns in any way. Of the 111 people (out of 244) who felt there were local environmental problems of any kind, only 28 reported any attempt to solve them. Most of the rest either did not know what to do (36/244) or felt any action would be useless (37/244). In the sections that follow we discuss various mechanisms that are available in rural China for speaking to environmental concerns, with particular attention to the problem of why people seem to use them so little.

\section{Law}

At first blush, one might not expect law to hold much promise as a means to address environmental concerns. After all, as Stanley Lubman reports, there continues to be considerable on-going aversion to formal legality. ${ }^{41}$ Over the past decade, however, China has increasingly sought to utilize public, positive law as one among many instruments to disseminate state norms and speak to important societal problems. ${ }^{42}$ Unlike the situation some 25 years ago, China's legal system today encompasses a large body of national law, a judicial system with a staff of some 350,000 and more lawyers than any other nation in Asia, save India, though many have had relatively modest legal education. ${ }^{43}$

The environment has proven no exception to this general pattern. China embarked on an ambitious program of environmental legal development soon after the conclusion of the Cultural Revolution. ${ }^{44}$ Beijing's efforts to utilize the law have not been limited simply to the promulgation of new rules. The recent elevation of the environmental protection agency to ministerial status, at

41. "Many among the populace are wary of litigation, dare not sue in the courts, and feel more comfortable settling disputes in the traditional manner of using intermediaries." Stanley B. Lubman, Bird in a Cage: Legal Reform in China After Mao (Stanford, CA: Stanford University Press, 1999), p. 220.

\section{Ibid.}

43. William P. Alford, "Tasselled Loafers for Barefoot Lawyers: Transformation and Tension in the World of Chinese Legal Workers," The China Quarterly, 141 (1995), pp. 22-39.

44. This has led Beijing to adhere to some 30 multilateral instruments concerning the environment, promulgate some 20 major national laws $(f a)$, and adopt some 500 national regulations (guiding), rules (guiding), measures (banfa), standards (biaozhun) and other legal enactments concerning the environment, natural resources and related issues. Many of these have been supplemented by sub-national legal enactments, while many of the most significant national laws have been targeted for revision as part of China's current multi-year legislative plan. William P. Alford and Yuanyuan Shen, "The Limits of the Law in Addressing China's Environmental Dilemma," in Michael B. McElroy, Chris P. Nielsen, and Peter Lydn, Energizing China: Reconciling Environmental Protection and Economic Growth (Cambridge, MA: Harvard University Committee on the Environment, 1998), pp. 405-430. 
a time when ministerial agencies are being cut back, is one sign of this. Official data suggest that Beijing's efforts to utilize law to promote the environment have, at least in official terms, reached Anhui province and perhaps even the counties that comprise Anqing. ${ }^{45}$ China Environmental Yearbook for 1995, for example, indicates that in 1994, propaganda and information efforts reached 10,550,000 persons in Anhui (roughly one sixth of the province's population). ${ }^{46}$ The 1996 Zhongguo Huanjing Nianjian (China Environmental Yearbook) also indicates that in 1995, some 3,396 citizens of Anhui availed themselves of the xinfang (letters and visits) procedure to register 1,158 written complaints and make 1,277 visits to officialdom concerning environmental matters. ${ }^{47}$ Of these, more (851) concerned air pollution than any other problem. ${ }^{48}$

In fact, however, our survey reveals very little use of the legal system. Of the 28 people who told us they had attempted to take action to overcome environmental problems (as noted above), only 5 said that they or their family members had ever gone to court regarding any matter. Only 3 reported that they or family members had ever used the services of a lawyer, even though more than one half of our respondents indicated that they believed that lawyers could effectively represent the interests of their clients. How does one reconcile what appears in the survey to be general concern about the environment, a belief that environmental problems exist, and a recognition that the law (through the intermediation of lawyers) may be of help with these very limited efforts to seek a solution and, in particular, very modest invocation of the law?

There were two principal reasons that respondents gave for taking no action with regard to environmental problems of which they were aware. First, 40 percent of those respondents who

45. Our survey was not designed to probe issues of the enforcement of these laws. We note, however, that Anqing's large cement factory was one of three in the entire province awarded a certificate for being an "All China Environmental Protection Advanced Enterprise" and that the discharge of emissions had reportedly been brought under control throughout some 85 percent of Anqing (Zhongguo Huanjing Nianjian, 1996, p. 326). At the same time, however, the authors of these reports also indicate their disappointment that expenditures for environmental matters constituted but 0.41 percent of the Anhui's gross domestic product, putting it significantly below the national average.

46. China Environmental Yearbook Editorial Committee, China Environmental Yearbook (English version), 1995, p. 288. The Yearbook does not provide the basis for this statistic.

47. Zhongguo Huanjing Nianjian, 1996, pp. 549-550. Given that this source reports 153,476 uses of the xinfang procedure for environmental issues throughout the country for the same period, Anhui's frequency appears well below the national average.

48. Ibid. Unfortunately, neither the environmental yearbooks nor other sources provide data as to the scope of environmental litigation, as cases are grouped according to the way in which Chinese courts are organized (i.e., along a criminal, civil, economic and administrative division, whereas environmental matters could conceivably arise under each of these categories). 
answered a question about why they failed to seek remedies to known difficulties attributed their inaction to a lack of knowledge about what they might do, while another 40 percent said that they thought any steps they might take would prove futile. These responses suggest to us that the issues of basic literacy and popular attitudes toward legal processes, among others, warrant further attention.

The response that a lack of knowledge was a prime reason for inaction is consistent with our findings reported above in the section on education, and with evidence about local familiarity with state measures. In spite of all the propaganda efforts reported in official sources, only 12 percent of respondents (29/244) indicated awareness of the government's environmental educational efforts and even fewer (18/244) knew of the much touted Air Pollution Law (and that figure may be too generous, as we purposely did not test those asserting acquaintance with it). Our conclusions above about the importance of education for environmental awareness also suggest that education would help the law become a more effective mechanism. For example, the 18 respondents who claimed knowledge of the Air Pollution Law tended to be appreciably better educated (as well as male and wealthier). Of those, 10 indicated that they had derived their knowledge from television.

Greater literacy may be especially useful for facilitating communication about and greater attention to law in general and the Air Pollution Law in particular. Much of contemporary Chinese law is written in general terms that fail to provide a clear statement of rights and responsibilities that can be communicated via a short broadcast, while subordinate legal measures (such as standards - biaozhun - which are of particular importance in the environmental area) are generally cast in terms far too technical for a lay audience. This problem of generality at the level of national legislation is particularly well illustrated with respect to the Air Pollution Law of 1995, the principal pertinent national statute at the time of our survey. As the product of a bitterly fought compromise between advocates of more stringent environmental controls and representatives of coal mining, heavy industry and associated provincial governments, this law is intentionally cast in broad, often ambiguous, and occasionally contradictory terms. ${ }^{49}$ In view of the low educational levels in rural Anqing, this hinders the use of environmental law to solve local problems.

The second principal reason cited by Anqing respondents for their failure to take action to

49. The Air Pollution Law has since (in 2000) been revised. See William P. Alford and Benjamin L. Liebman, "Clean Air, Clear Processes? The Struggle Over Air Pollution Law in the People's Republic of China," forthcoming Hastings Law Journal (2001). 
remedy environmental concerns--the belief that such action would be futile--suggests that more may be needed than greater literacy. Specifically, the fact that two-thirds of respondents believed that lawyers could not affect the outcome of their case, even though more than one half of all respondents believed that lawyers could effectively represent clients' interests suggests some doubt about the efficacy of formal legal processes. Some confirmation for this can be found in our anecdotal data, in which some respondents seemed to take umbrage at merely being asked if they or their family had ever been gone to court, as if it suggested untoward behavior on their part. We hope to learn in future research the degree to which unease about the court system is a product of lingering historic suspicions about the law, a more generalized contemporary dubiousness about whose interests state institutions serve, or other factors.

In addition to learning more about popular attitudes toward the courts, we also hope to gain greater acquaintance with such matters as the readiness of different groups (men/women, the more/less educated, the more/less affluent) to avail themselves of the law; the cost, timeliness, accessibility, and receptivity (in terms of rules on standing and procedure) of courts; the availability, reputation and utility of lawyers; concerns (warranted or not) about the corruption of, competence of, and retaliation by persons associated with or ensnared in legal processes; beliefs about the impact of invoking formal legal processes upon one's local social standing; and the relative efficacy of letters and visits, mediation and other processes apart from litigation.

\section{Elections and Participation in Village Affairs}

Elections for the village committee as well as participation in village committee meetings and village politics represent another means through which citizens might raise concerns about environmental affairs. Village committees may also play an important role in underscoring the state's seriousness about environmental matters. Instituted on a trial basis in the aftermath of the 1987 Organic Law on Village Committees of the PRC, village elections have spread relatively quickly throughout the country, due both to popular support and the recognition by some state

leaders that such local elections could stabilize rural society. ${ }^{50}$ By 1992 , elections had occurred in most provinces and autonomous regions and by 1993, according to official sources, over 90 percent of village committees nationwide were elected, although the extent to which they were

50. Allen C. Choate, "Local Governance in China: An Assessment of Villagers Committees," The Asia Foundation Working Paper Series 1 (1997). This law was designed to effectuate Article 111 of the 1982 Constitution of the PRC. 
fully democratic varies significantly. ${ }^{51}$

Scholarly and more popular interpretations of these elections vary. Many observers, from academe to government circles to the media, have praised them for increasing the levels of villager political participation and the quality of grassroots governance. ${ }^{52}$ Elections have reportedly helped the state institute difficult policies, such as birth control, and have made it easier for local cadres to tax villagers and get them to contribute somewhat willingly to public works projects. ${ }^{53}$ To this extent, village committees should become an important conduit for implementing the state's environmental policies. Most importantly for our study, Manion argues that elections increase the level of congruence between the attitudes of villagers and their elected representatives, particularly as concerned economic development. ${ }^{54}$

Village committee elections in Anqing are held every three years, with the exact method varying considerably among villages. However, the level of participation in village committee elections and in village committee meetings is generally not high, suggesting that this is not likely to be a major medium through which Anqing's villagers express their concerns (assuming, of course, they have them). Only one-third of villagers surveyed (82/244) had voted in any election, although male participation rates (45 percent) were significantly higher than female rates (24 percent). Villagers were not that keen about these elections. When asked how interested they were in village committee elections, only 9 percent were "very interested," 18 percent were "relatively interested," 19 percent were "not too interested," and 54 percent were "not interested at all."

Answers to two other questions may explain limited interest in elections. First, villagers do not believe that elected representatives are very influential. When asked who are the powerful people in the village, most selected cadres while only 8 percent (20/236) of our respondents selected "people's elected representatives." The view that elected representatives do not have

51. Xu Wang, et al., "Association between air pollution and low birth weight: a community-based study," Environmental Health Perspectives, 105, 5 (May 1997), pp. 514-520. Interestingly, Guangdong Province began its elections only in 1998.

52. Choate, "Local Governance"; Minxi Pei, "Is China Democratizing?" Foreign Affairs, JanuaryFebruary, 1998; Wang, "Low birth weight"; Thomas L. Friedman, "It Takes a Village," The New York Times, March 10, 1998.

53. Wang, "Low birth weight."

54. Melanie Manion, "The Electoral Connection: The Chinese Countryside," American Political Science Review 90 (December 1996), pp. 736-748. 
much power reflects their second important perception: that most people who are elected are cadres (24 percent) or village officials (47 percent) in the first place, suggesting that power is based on being selected by higher-level authorities, rather than derived from any popular mandate. Thus, more than two-thirds of respondents (69 percent or 168/244) indicated that they did not believe that elections influenced village affairs, while only 12 percent (29/244) held a contrary view.

Elections, however, are not that effective a format by which the electorate can express its views on the environment or other issues; participation in meetings or influencing the selection of candidates are better media. Speaking in a meeting allows one to articulate a particular grievance, while voting does not. Yet villagers also generally eschewed these more effective modes of interest articulation. Only 10 percent (25/244) of the interviewees had ever attended a village committee meeting. Of those who did, only five people (20 percent of those who ever attended, but just 2 percent of the entire sample) spoke of being motivated to attend a village committee meeting because of some important issue. ${ }^{55}$ Even among the 25 attendees, 68 percent did not speak but only listened, leaving only seven activists (32 percent) who either made their opinion known on some issue or tried to influence the opinions of others. ${ }^{56}$ Perhaps villagers do not need to act because local cadres already share their concerns and are likely to act to improve the environment. Thus, we asked a series of questions to tap into these issues. Interestingly, our data do suggest some support for Manion's congruence hypothesis: Anqing villagers see themselves placing general importance on environmental protection, and they also see the village committee sharing these values. As Figure 1 shows, the distribution of villagers' values toward environmental protection and their perception of cadres' values are very similar.

In spite of this, villagers did not feel that environmental protection was a top priority for village committees. When we asked which of twelve issues they believed that village committees ranked as important, respondents placed family planning, education, medical services, and taxes/fees at the head of the list, with environmental protection lagging rather far behind (chosen by just 6 percent, 15/244). ${ }^{57}$ Of the 15 people who believed that the village committee actually

55. Of the others who attended these meetings, 24 percent $(6 / 25)$ said that they did so because they "had to," and 44 percent (11/25) claimed to "always" attend.

56. Speaking at meetings can be dangerous in Chinese politics. Nathan and Shi's (1993) work suggests that rural Chinese show very little tolerance for dissenting views expressed in public meetings, relative to their counterparts in six other nations.

57. Respondents could choose more than one. Family planning was chosen by 68 percent, education by 50 percent, medical services by 39 percent, and taxes and fees by 32 percent. 
pays attention to the environment, 6 believed that local pressure from the masses made them so do, while seven saw upper-level pressure as critical. This finding differs drastically from the issues of taxes, family planning and education, where villagers perceived village committee attention to these issues as the result of pressure from higher level authorities. On the other hand, of all issues that villagers felt the village committee should discuss but did not, 24 people selected the environment, second only to taxes which was selected by 27 people, but ahead of public security (22) which ranked third. Even more surprising was the fact that only 9 people felt that corruption was an important issue that was not being discussed. ${ }^{58}$

Finally, the lack of participation on environmental issues may result from two factors. First, villagers in general did not participate in any aspect of village affairs. Thus, when asked how frequently they participate in village affairs in general, 82 percent (202/244) did not see themselves as participating at all--despite the fact that some of these people had voted. ${ }^{59}$ Second, environmental problems may result from external forces beyond the village and so may be managed, if at all, by higher-level officials over whom villagers have little influence. Thus neither elections nor village committee meetings may necessarily be useful fora for influencing environmental issues. It may be that villagers will turn to petitioning higher level officials (shang fang gao zhuang) or to forms of civil disobedience when their ire about environmental issues arises. $^{60}$

\section{Conclusion}

To the extent that our localized findings and relatively small sampling permit us to extrapolate conclusions, they suggest that efforts by the Chinese state to foster the implementation of policy concerning the environment through such institutional innovations as the promulgation of environmental law and the promotion of elections at the village committee level have yet to take hold in any widely discernible fashion, at least in Anqing. We have noted the relatively extensive publicity focused on environmental affairs in Anhui as a result of the Huai River cleanup campaign, and as a result we expected more familiarity with, if not adherence to, these policy

58. The relative importance given to the environment may reflect a bias in the data as by this point in the interview process, villagers had probably realized that the environment was the key focus of our study; therefore, they may have begun to impart more value to it that they really felt.

59. A further 26/244 felt that they participated "somewhat," while only 11 saw themselves as "always" participating. 
measures in Anqing than in the nation more generally.

Judging from our preliminary inquiry, it seems that if the state wishes to foster more attention to the environment, it will need, among other things, both to accentuate education and to demonstrate better to village committees that it values the environment. By education, we mean in particular basic literacy and general education. This is especially important for women who appear more vulnerable to indoor pollution by virtue of their present domestic responsibilities and who, nonetheless, tend to be appreciably less well educated. Targeted education regarding environmental harms and possible remedial measures through law, among other means, also seem appropriate, but are not likely to be effective without more fundamental education. The availability of television may serve as a valuable vehicle for such educational efforts, although we have yet to ascertain how widely and evenly spread viewing is among different segments of the Anqing populace. Our data also suggest that environmental information focusing on the health effects of pollution might be especially effective.

Education about the environment also needs to be accompanied by a greater state commitment to its environmental policies. Our findings suggest that the populace views local village committees as capable of reflecting well the priorities of higher authorities. At present, our sample of people in rural Anqing does not seem to believe that this includes placing a high priority on the environment, in spite of local interest in such matters and a sense that the relevant village committees would not be reluctant to advance such policies if so instructed. State interest is also significant, if perhaps yet harder to realize, with regard to the role of bureaucratic actions. Giving environmental protection ministerial status in Beijing does not necessarily address the relative position of local environmental protection bureaus, nor does it speak to the economic and other pressures that may make it difficult for local level environmental officials to discharge their responsibilities suitably.

In the end, perhaps the problem is not only one of constructing institutions or passing laws, but of actually reaching the populace with the message about environmental needs and policies.

60. Jun Jing, "Environmental Protests in Rural China." 